\title{
Breeding Performance of the Red-Backed Shrikes (Lanius collurio) in a Riparian Habitat
}

\author{
Kızılsırtlı Örümcekkuşunun (Lanius collurio) Bir Riperyan \\ Habitattaki Üreme Performansı
}

\author{
Research Article
}

Necmiye Şahin Arslan ${ }^{*}$, Zafer Ayaş²

${ }^{1}$ Hitit University, Faculty of Art and Sciences, Department of Biology, Corum, Turkey. ${ }^{2}$ Hacettepe University, Faculty of Science, Department of Biology, Ankara, Turkey.

\section{A B S TR ACT}

W e investigated the breeding performance and nest site properties of the red-backed shrikes in a small population in Nallihan Bird Sanctuary in Turkey. We carried out the field studies during the 2006 and 2007 breeding seasons. We monitored 12 nests of 7 breeding pairs in the 2007 breeding season. Most of the territories were near the Aladag Stream-Riparian Habitat. The distance between the nests were $110 \pm 20 \mathrm{~m}$. The red-backed shrikes built their nests in the thorny bushes at the average height of $80 \pm 32.5 \mathrm{~cm}$ above the ground. Only one pair could raise fledglings within the monitored pairs. Four Nests were predated during the incubation and four nests were predated during nestling stage in the 2007 breeding season. Yet, the previous year we had detected at least one fledgling within 6 of the 8 territories. We estimated that this small population had suffered from high nest predation at the Nallihan Bird Sanctuary after a successful breeding season. Long-term studies are required to obtain more detailed information about the populations of the red-backed shrikes in Turkey.

\section{Key Words}

The red-backed shrike, breeding biology, nest site.

\section{ÖZET}

u çalışmada, kızılsırtlı örümcekkuşunun Nallıhan Kuş Cenneti'ndeki küçük bir populasyonunun üreme performansı ve yuva yeri özellikleri araştııılmıştır. Saha çalışmaları 2006 ve 2007 üreme dönemlerinde gerçekleştirilmiştir. 2007 üreme döneminde 7 üreme çiftine ait 12 yuva takip edilmiştir. Teritoryumların büyük çoğunluğunun Aladağ Çayı riperyan habitatında bulunduğu kaydedilmiştir. Yuvalar arasındaki mesafe $110 \pm 20$ m'dir. Kızılsırtlı örümcekkuşları yuvalarını dikenli çalılara, yerden ortalama $80 \pm 32.5 \mathrm{~cm}$ yüksekliğe yapmışlardır. Takip edilen çiftlerden yalnızca bir tanesi kanatlanmış yavrular yetiştirebilmiştir. 2007 üreme döneminde dört yuva inkübasyon, dört yuva da yavru aşamasında predasyona uğramıştır. Buna rağmen, bir önceki üreme döneminde 8 teritoryumun içinde 6 tanesinde kanatlanmış yavrular gözlenmiştir. Bu küçük populasyonun başarılı bir üreme dönemi sonrası maruz kaldığı yoğun yuva predasyonu nedeniyle başarısız olduğu tahmin edilmektedir. Türkiye'deki kızılsırtı örümcekkuşu populasyonları hakkında daha ayrıntılı bilgi sahibi olmak için uzun dönemli çalışmalara intiyaç vardır.

\section{Anahtar Kelimeler}

Kızılsırtlı örümcekkuşu, üreme biyolojisi, yuva yeri.

Article History: Received: Oct 18, 2015; Revised: Nov 22, 2015; Accepted: Nov 28, 2015; Available Online: Dec 30, 2015 DOI: $10.15671 /$ HJBC.20154315984

Correspondence to: N. Şahin Arslan, Hitit University, Faculty of Art and Sciences, Department of Biology, Corum, Turkey. 


\section{INTRODUCTION}

Dredation has been assumed to be an important case of the nest failures in different habitats [1-3] and several studies of terrestrial birds have shown higher rates of nest predation among the open-nesting species than among compared with the cavity-nesting species [2]. The red-backed shrikes, Lanius collurio are medium-sized migrant songbirds. They are territorial and the breeding pairs defend their breeding sites. They build open cup nests particularly in shrubs with a height of 1-1.5 $\mathrm{m}$. They are single brooded but if they fail, they usually build a new nest and they have a new breeding attempt [4]. The red-backed shrikes have been evaluated as "declining" according to the European Threat Status in breeding sites for all of Europe [5]. It is known that this species breeds regularly in Turkey [6]. Defining the nest success and the nest predation rate of the threatened open cup nested songbirds is crucial part of producing management plans.

We aimed to determine the breeding performance of the red-backed shrikes in a small population in the Central Anatolia Region of Turkey. We observed the red-backed shrike population at the Nallihan Bird Sanctuary, which is an important bird area in Turkey.

\section{STUDY AREA AND METHOD}

The study was conducted at the Nallihan Bird Sanctuary -a national protection site, with an approximate area of 451 ha. At the northern part of the Sariyar Reservoir $\left(40^{\circ} 06^{\prime} \mathrm{N}\right.$ and $31^{\circ}$ $36^{\prime}$ E) the Aladag Stream forms a delta and flows into a lake. This area is known as the Nallihan Bird Sanctuary in the province of Ankara, Turkey. The study area is consisted of densely vegetated areas near the Aladag Stream, agricultural areas and steppe-vegetated hilly areas with scarce bushes. The study area can be seen in Figure 1 [7]

Field studies were carried out from April to September in years in 2006 and 2007. In the first year we did not focus on locating the nests. We visited the nests weekly to avoid any possible influence of the visits on the nest predation rate [8]. The distance between the nests from the first attempts of the breeding pairs were determined using a Global Positioning System (GPS) device. The nest plant species, their heights, the height of the nests from the ground and other nest properties (e.g height and diameter) were recorded for all the nests that were detected during the 2007 breeding season. The quantitative results were presented as "mean values \pm standard deviation".

\section{RESULTS}

The red-backed shrikes at the study area were seen first in the beginning of early May. The number of birds reached its maximum in midMay, in both years. (Figure 2). Only breeding pairs stayed at the study area in the last days of May.

We determined 8 breeding territories in the study area during the 2006 breeding season but we did not locate their nests. Only one of them was far from the Aladag Stream, which was located on a pasture land near an agricultural area. We detected that most of the territories in 2006 were also occupied in 2007 by the breeding pairs. In 2007, whilst 6 of 7 breeding pairs' nests were near the Aladag Stream, the other one was located in a hilly area. The territories near the Aladag Stream were along a $500 \mathrm{~m}$ transect and nests were close to each other $(110 \pm 20 \mathrm{~m}, \mathrm{n}=5)$.

Most of the nests were in blackberry bushes (Rubus discolor). All the nest supporting plants found in the study area provided in Table 1.

The nest supporting plants were recorded to be $211 \pm 120 \mathrm{~cm}(n=10)$ tall. The nests were built at the height of $80 \pm 33 \mathrm{~cm}(n=10)$ above the ground. The diameter and height of the nests were $11.6 \pm$ $0.9 \mathrm{~cm}$ and $6.4 \pm 1.0 \mathrm{~cm}(\mathrm{n}=9)$, respectively.

During the 2007 breeding season, 7 breeding pairs were monitored. While one of the nests was located during the nestling period, while the others were located during the nest construction and egg-laying stage. Because we did not check the nests daily, we could not determine the exact clutch size of the nests. Yet, we recorded a minimum of 5 and a maximum of 6 eggs/nestlings within the nests. 


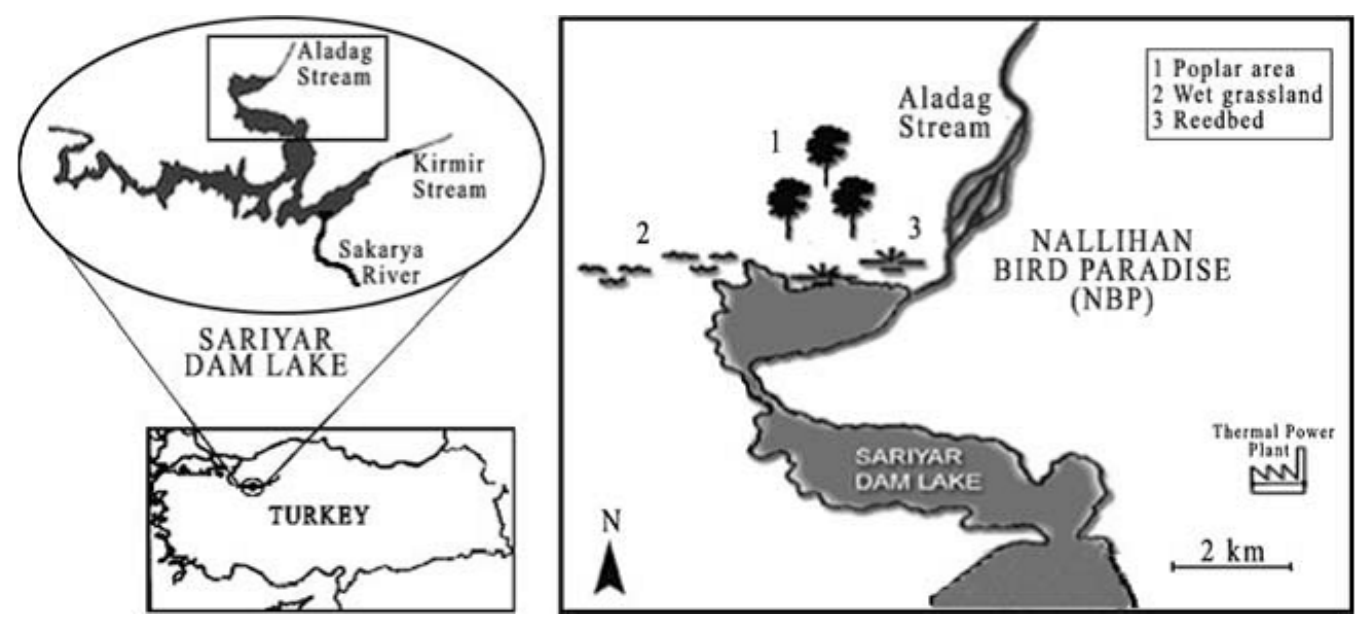

Figure 1. Study area-Nallihan Bird Sanctuary [7].
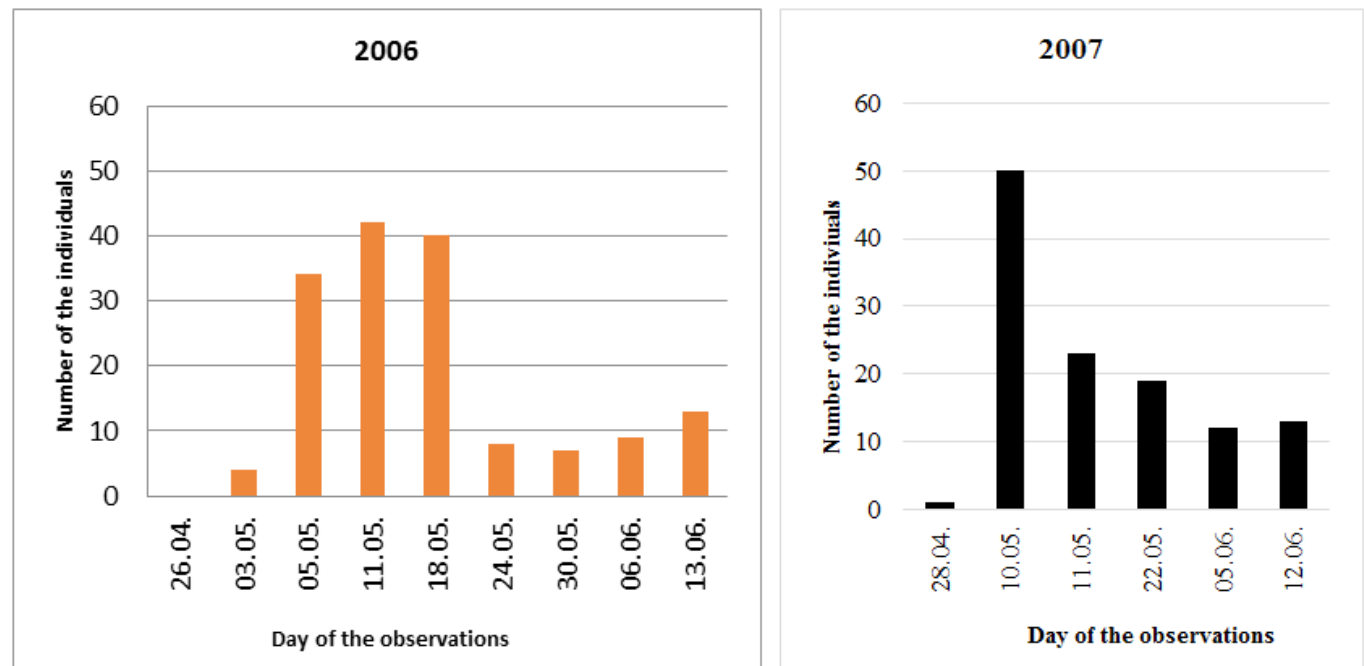

Figure 2. The numbers of the red-backed shrikes in the first part of the two breeding season.

Table 1. The plant species that the red-backed shrikes were built on at the Nallihan Bird Sanctuary during the 2007 breeding season.

\begin{tabular}{cc}
\hline Plant species & Number of the Nests \\
\hline Rosa sp. & 1 \\
\hline Paliurus spina & 1 \\
\hline Rubus dicolor & 5 \\
\hline Rhamnus sp. & 2 \\
\hline Ficus carica & 1 \\
\hline
\end{tabular}

We also observed the fledglings within 6 of the 8 territories in late June and throughout July of 2006. All of the 7 nests were depredated during the 2007 breeding season. One of the pairs abandoned its territory. The others built new nests near their predated nests. Whilst the abandoned nests included the some parts of nest contents, we did not detect any in the other failed nests.

When we evaluated all of the breeding attempts, only one of the 12 nests was successful 
in the 2007 breeding season. Among all the monitored pairs, only one pair grew up to be fledglings in their third breeding attempt. Four of the nests were predated during incubation and another four were predated during nestling stage. We detected a pair that built three nests at different times during the 2007 breeding season but interestingly we did not recognize any eggs or chicks at these nests.

We did not witness any predation event. Some potential nest predators were seen at the study site, either observed at the nest sites or their surroundings (e.g. the red fox-Vulpes vulpes, the domestic cat-Felis silvestris, the hooded crowCorvus cornix, and the Eurasian magpie-Pica pica). There were also a number of small mammal nest holes near the red-backed shrike nest sites.

\section{DISCUSSION}

The Nallihan Bird Sanctuary is an important area for the red-backed shrikes. The results of this study showed that Nallihan Bird Sanctuary was used both as a stopover and breeding area by the shrikes. According to our results, in this area the breeding success of the red-backed shrikes showed annual variation. While most of the pairs were successful in 2006, the breeding success in 2007 was extremely low due to nest predation.

Re-occupation of the same breeding sites after a successful breeding season was an expectable case for the red-backed shrikes in our study area. According to habitat copying hypothesis, animals use the breeding performance of their conspecifics as a cue for making decision on their future breeding sites $[9,10]$.

Nest predation is the primary cause of breeding failure in most of the bird species [11]. The redbacked breeding in grasslands in south-central Sweden breeding in grasslands were reported to have a nest predation rate of 39\% [12]. Nikolov (2004) and Pasinelli et al. (2007) suggested that about $68 \%$ and $66 \%$ of the nest loses resulted from the predation events [13]. Besides the red-backed shrikes, nest predation is the most important factor that influences the breeding success of the other shrike species [14-16]. Nest predation risk plays a crucial role in the decisions of songbirds to settle in a particular habitat [17]. This species favors shrubby pastures and habitats with sustained low vegetation allowing good visibility of the ground living beetles $[18,19]$. In the Nallihan Bird Sanctuary, the red-backed shrikes preferred to breed in dense vegetation near the stream but they rarely used agricultural areas and the hilly areas with steppe vegetation as breeding territories. It was revealed that the population of the red-backed shrikes was under intense nest predation pressure in some seasons at the Nallihan Bird Sanctuary. They might have built their nests in dense vegetation because of the nest predation pressure. In this area, building well-concealed nests could be a strategy to avoid nest predation for the red-backed shrikes. On the other hand, the nests near the Aladag Stream were in a close proximity to each other compared to distances mentioned in other studies $[20,21]$. This might have been one of the causes of the high nest predation rate, facilitating the availability of the nests to predators [22]. On the contrary, in some cases, population density and predation risk show an inverse relationship [23]. Despite our sensitive treatments, observer effect could have been another reason for high nest predation rate $[24,25]$.

In conclusion, nest predation is a vital factor on the life history traits of birds [26] and so nest predation studies are very important to gain a deeper understanding of the life of birds.

\section{ACKNOWLEDGEMENTS}

We are grateful to the late Ali Celal Hoş for his support in our study.

\section{References}

1. R.E. Ricklefs, An Analysis of Nesting Mortality in Birds. (1969)

2. M. Willson, S. Gende, Nesting success of forest birds in southeast Alaska and adjacent Canada. The Condor, 102 (2000) 314-325.

3. Q. Wang, X. Zhou, F. Li, Y. Zhang, F. Li, Nest site characteristics and nest loss of Marsh Grassbird at Zhalong National Nature Reserve, China. J. For. Res., 26 (2015) 785-790.

4. N. Lefranc, T. Worfolk, Shrikes. A Guide to the Shrikes of the World., (1997)

5. G. M. Tucker, M. I. Evans, Habitats for Birds in Europe: A Conservation Strategy for the Wider Environment., (1997). 
6. G. Kirwan, B. Demirci, H. Welch, K. Boyla, M. Özen, P. Castell, T. Marlow, The Birds of Turkey, (2008)

7. Z. Ayaş, Trace element residues in eggshells of grey heron (Ardea cinerea) and black-crowned night heron (Nycticorax nycticorax) from Nallihan Bird Paradise, Ankara-Turkey, Ecotoxicology, 16 (2007) 347-352.

8. R.E. Major, The effect of human observers on the intensity of nest predation, Ibis, 132 (1990) 608-612.

9. E. Danchin, B. Heg, B. Doligez, Public information and breeding habitat selection, in Dispersal, J. Clobert, E. Danchin, A.A. Dhondt, and J.D. Nichols, eds., (2001) 243-258.

10. B. Doligez, E. Danchin, J. Clobert, Public information and breeding habitat selection in a wild bird population, Science, 297 (2002) 1168-1170.

11. T.E. Martin, Avian life history evolution in relation to nest sites, nest predation and food, Ecol. Monogr., 65 (1995) 101-127.

12. B. Söderström, T. Pärt, J. Rydén, Different nest predator faunas and nest predation risk on ground and shrub nests at forest ecotones: an experiment and a review, Oecologia, 117 (1998) 108-118.

13. G. Pasinelli, M. Müller, M. Schaub, L. Jenni, Possible causes and consequences of philopatry and breeding dispersal in red-backed shrikes Lanius collurio, Behav. Ecol. Sociobiol., 61 (2007) 1061-1074.

14. A. Kristin, H. Hoi, F. Valera, C. Hoi, "Breeding biology and breeding success of the Lesser Grey Shrike Lanius minor in a stable and dense population, Ibis, 142 (2000) 305-311.

15. P. Isenmann, G. Fradet, Nest site, laying period, and breeding success of the Woodchat Shrike (Lanius senator) in Mediterranean France, J. Fur Ornithol., 139 (1998) 49-54.

16. Z. Brahimia, H. Dziri, S. Benyacoub, Y. Chabi, J. Ba bura, Breeding ecology of Algerian woodchat shrikes Lanius senator: low breeding success, Folia Zool., 52 (2003) 309-316.
17. J.J. Fontaine, T.E. Martin, Habitat selection responses of parents to offspring predation risk: an experimental test, Am. Nat., 168 (2006) 811-818.

18. J.K. Svendsen, P.K. Bøcher, J.-C. Svenning, Habitat and nest site preferences of Red-backed Shrike (Lanius collurio) in western Denmark, Ornis Fennica, 92 (2015) 63-75.

19. V. Olsson, The Red-backed Shrike Lanius collurio in southeastern Sweden: Habitat and territory, Ornis Svecica, 5 (1995) 31-41.

20. S. Kuniak, P. Tryjanowski, Distribution and breeding habitat of the red-backed shrike (Lanius collurio) in an intensively used farmland, Ring, 22 (2000) 89-93.

21. R. Horváth, R. Farkas, R. Yosef, Nesting ecology of the red-backed shrike (Lanius collurio) in Northeastern Hungaria, Ring, 22 (2000) 127-132.

22. T.E. Martin, Processes organizing open-nesting bird assemblages: competition or nest predation, Evol. Ecol., 2 (1988) 37-50.

23. D.M. Visco, T.W. Sherry, Increased abundance, but reduced nest predation in the chestnut-backed antbird in costa rican rainforest fragments: surprising impacts of a pervasive snake species, Biol. Conserv. 188 (2015) 22-31.

24. E. Nol, R.J. Brooks, Effects of predator exclosures on nesting success of killdeer, Journal of Field Ornithology, 53 (1982) 263-268.

25. R. Major, The effect of human observers on the intensity of nest predation, Ibis, 132 (1990) 608-612.

26. A. Basso, H. Richner, Effects of nest predation risk on female incubation behavior and offspring growth in great tits, Behav. Ecol. Sociobiol., 69 (2015) 977-989. 
